MOL2NET, International Conference Series on Multidisciplinary Sciences

CHEMBIOMOL-07: Chem. Biol. \& Med. Chem. Congress, Bilbao-Rostock, Germany, Galveston, USA, 2021

sciforum

\title{
Effect of the re-growth age on the primary metabolites of Tithonia diversifolia, part 2: Sugars metabolism.
}

Maidelin Paumier ${ }^{a}$, Danis Verdecia ${ }^{a}$,Hernán Uvidia ${ }^{c}$, Jorge Ramírez ${ }^{a}$, Rafael

Herrera $^{b}$, Jhoeel Uvidia, Edgar Chicaiza ${ }^{c}$, Angel Santana ${ }^{a}$.

\author{
${ }^{a}$ Universidad de Granma, Apartado Postal 21, Bayamo Granma, Cuba (C.P. 85 100). \\ ${ }^{b}$ Instituto de Ciencia Animal (ICA), Apartado Postal 24 San José de las Lajas, \\ Mayabeque; Cuba. \\ ${ }^{c}$ Universidad Estatal Amazónica, Puyo, Pastaza, Ecuador. \\ ${ }^{e}$ Universidad Politécnica de Valencia. Valencia, España.
}

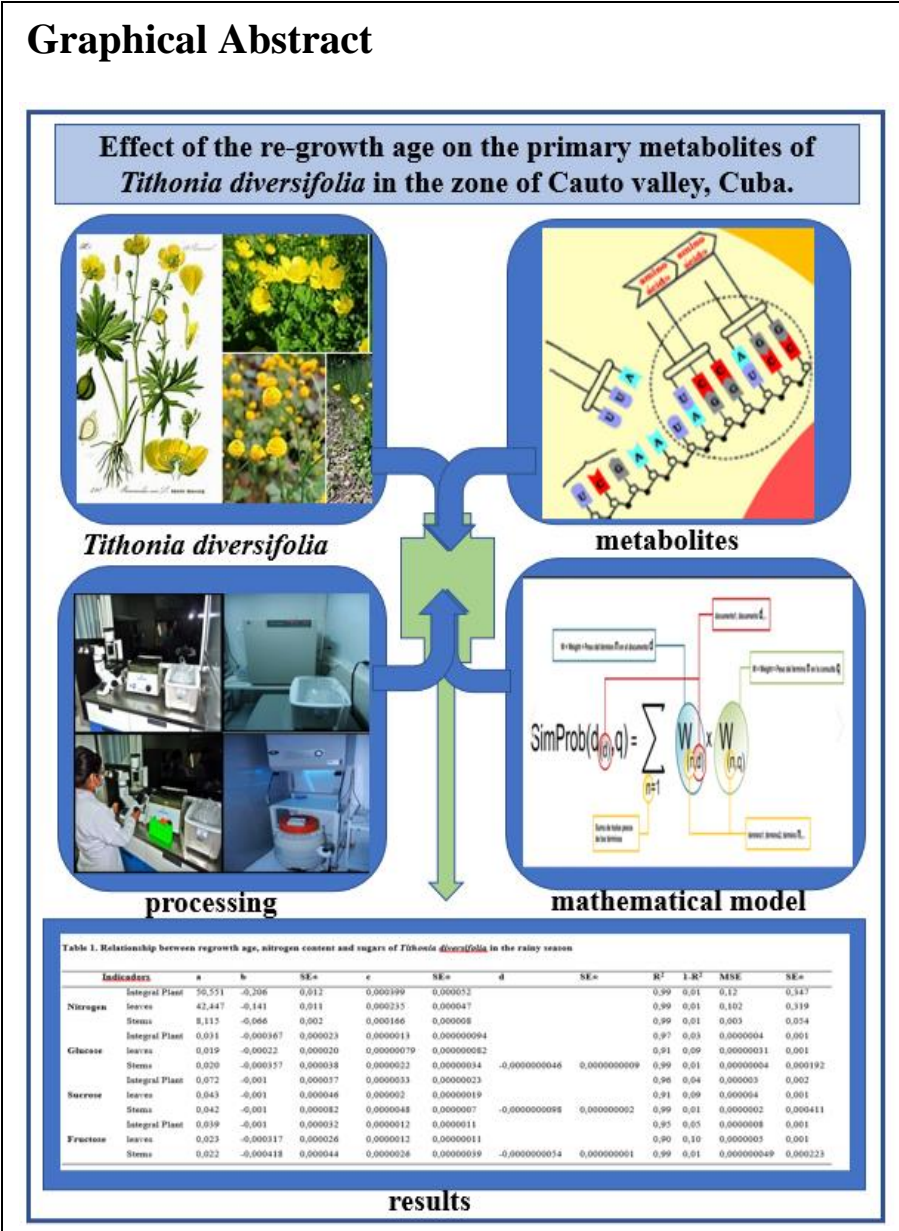

\begin{abstract}
.
The primary metabolites, very abundant in nature, are essential for the physiological development of the plant; they are present in large quantities, they are easy to extract, and their exploitation is relatively cheap. In order to establish mathematical expressions that relate the regrowth age with the nitrogen and sugar content (glucose, fructose and sucrose) of the whole plant and its fractions. The experiment was developed, following a randomized block design, with 5 treatments $(60,90,120,150$ and $180 \mathrm{~d})$. In the first part of this communication the content of Nitrogen $(N)$ in the integral plant, leaves and stems were evaluated. In the second part we studied sugars like Glu, Frut and Suc. Reporting that N, Glu, Frut and Suc decreased with the highest results at 60 days and quadratic and cubic equations with $R 2$ higher than 0.90 were adjusted. The established regression equations explain the close relationship between regrowth age and the contents of precursor metabolites $(N$, Glu, Frut and Suc), which explains the fluctuations found in sugars influenced by the
\end{abstract}


phenological state of the plants and photosynthetic activity of this.

\section{Introduction}

Tithonia diversifolia is a shrubby herbaceous species with showy yellow flowers. It has great adaptability, the same can be found at sea level or at an altitude of approximately $2400 \mathrm{~m}$ it can inhabit soils of high or low fertility. It has additional benefits for erosion control, it can be used as food for the animal, with high nitrogen content and a source of carbohydrates ${ }^{[1]}$.

The role of Mathematics and its applications has been different in the spheres of human activity and in different times. It was formed historically under the considerable influence of two factors: the level of development of the mathematical apparatus and the degree of maturity of the knowledge about the object of study; as well as the possibility of describing its most important features and properties in a language of symbols and equations or, as has often been said, the possibility of building a mathematical model of the object to be studied ${ }^{[2]}$.

Mathematical modeling is a very useful tool in different disciplines of knowledge. In Cuba, this technique has been developed in the animal branch ${ }^{[3]}$. However, in studies with plants, specifically in the evaluation of pastures, the works are more incipient and limited ${ }^{[1]}$.

For all the above, the objective is to establish mathematical expressions that relate the regrowth age with the nitrogen and sugar content of the whole plant and its fractions.

\section{Materials and Methods}

The study was developed in the Teaching-Productive Department of the University of Granma, which is located in the southeast of Cuba, in the province of Granma, $17.5 \mathrm{~km}$ from the city of Bayamo. The experiment was carried out for two years, and two periods were considered, the rainy one (May-October) and little rainfall (November-April).

The soil present in the area was Calcium brown ${ }^{[4]}$, with a $\mathrm{pH}$ of 6.2 . The content of $\mathrm{P}_{2} \mathrm{O}_{5}, \mathrm{~K} 2 \mathrm{O}$ and total $\mathrm{N}$ was $2.4 ; 33.42$ and $3(\mathrm{mg} / 100 \mathrm{~g}$ of soil) respectively, with $3.6 \%$ organic matter.

Regarding the behavior of the climatic variables, during the rainy period, the precipitations were $731.4 \mathrm{~mm}$; the average, minimum and maximum temperature and relative humidity registered values of $26.73 ; 22.31$ and $33.92{ }^{\circ} \mathrm{C}$ and $80.78 ; 51.02$ and $96.22 \%$, respectively. 
In the second period, the rainfall reached values of $270 \mathrm{~mm}$; the temperature was $24.05 ; 18.29$ and $31.58{ }^{\circ} \mathrm{C}$ and the relative humidity of $76.21 ; 44.16$ and $97.03 \%$, in both cases for the mean, minimum and maximum averages.

\section{Treatment and experimental design}

A randomized block design with four replications was used and the treatments were regrowth ages of $60,90,120,150$ and 180 days.

\section{Procedures}

The already established species had $98 \%$ population and at the beginning of each seasonal period a homogeneity cut was made at $15 \mathrm{~cm}$ above ground level. The samplings were carried out in 10 plants in a row, eliminating the edge effect in an area of 0.5 ha- 1 , according to the treatments. The sample was homogenized and weighed, later they were separated manually into leaves, petioles and stems with a diameter of less than two centimeters. Then two kilograms were taken for each of the treatments to determine the dry matter (DM). During the experimental stage neither irrigation nor fertilization was applied.

\section{Chemical analysis}

The samples were dried at room temperature in a dark and ventilated room for 12 days, then they were ground to a particle size of one millimeter and stored in amber bottles at room temperature until their analysis. The following were determined: DM and $\mathrm{N}$ according to ${ }^{[5]}$, while the glucose, fructose and sucrose contents according to the Lane and Eynon titration method, which is based on the reduction of $\mathrm{Cu}+2$ to $\mathrm{Cu}+1$ by the reducing sugars, using methylene blue as indicator ${ }^{[5]}$.

\section{Statistical calculations and analysis}

The relationship between age with nitrogen and sugars was established through regression analysis where the following were used: linear, quadratic, cubic, logarithmic and gompertz, where the results with the highest adjustment were used for what they were considered. the criteria of ${ }^{[2,6,7]}$. For this, the statistical program SPSS version 22 was used.

\section{Results and Discussion (optional)}

The contents of glucose (Glu), sucrose (Suc) and fructose (Frut) during the rainy period in T. diversifolia (Table 1) decreased with the regrowth age in $(13.15 ; 9.99,3.16)$, (0.0091, 0.0051, 0.0048), (0.0213, 0.0117, 0.0095), (0.0117, 0.0029, 0.0047 g / Kg) each one of the indicators for the integral plant (IP), leaves and stems, respectively. Quadratic equations were adjusted for all the indicators except for the stems of glucose, sucrose and fructose, which presented cubic functions.

This species during the dry season (Table 2) maintained a similar behavior with adjustments for the quadratic equations, except for glucose in the leaves that presented cubic. The highest values were obtained at 60 days for nitrogen, glucose in the plant and in the 
stems; sucrose in the whole plant and the stems with a decrease in Glu (0.002; 0.0021), Suc $(0.0046 ; 0.0032 \mathrm{~g} / \mathrm{Kg})$, respectively. The rest of the indicators maintained a poorly defined behavior with the best grades at 120 days. The set of chemical reactions that take place in an organism constitutes metabolism.

They are amino acids, nucleotides, sugars, and lipids, present in all plants and performing the same functions. They are called primary metabolites ${ }^{[8]}$.

The adjusted models and the R2 values reported in tables 1 and 2 are like those reported by ${ }^{[9,10,11]}$ when evaluating the effect of age and climatic factors on the content of nitrogen in forage species in the Cauto Valley. The decrease in $\mathrm{N}$ with the cutting frequency may be related to a reduction in the synthesis of protein compounds, a decrease in the number of leaves, an increase in the stem fraction and an increase in the production of structural carbohydrates (cellulose and hemicellulose), although it is important to note that the values in both periods in each species exceeded $22.4 \mathrm{~g} / \mathrm{Kg}$. 
Table 1. Relationship between regrowth age, sugars content sugars of Tithonia diversifolia in the rainy season

\begin{tabular}{|c|c|c|c|c|c|c|c|c|c|c|c|c|}
\hline \multicolumn{2}{|c|}{ Indicadors } & \multirow{2}{*}{$\begin{array}{l}\mathbf{A} \\
0,031\end{array}$} & \multirow{2}{*}{$\begin{array}{l}\mathbf{b} \\
-0,000367\end{array}$} & \multirow{2}{*}{$\begin{array}{l}\text { SE } \pm \\
0,000023\end{array}$} & \multirow{2}{*}{$\begin{array}{l}\mathbf{C} \\
0,0000013\end{array}$} & \multirow{2}{*}{$\begin{array}{l}\text { SE } \pm \\
0,000000094\end{array}$} & \multirow[t]{2}{*}{ d } & \multirow[t]{2}{*}{ SE \pm} & \multirow{2}{*}{$\begin{array}{l}\mathbf{R}^{\mathbf{2}} \\
0,97\end{array}$} & \multirow{2}{*}{$\begin{array}{l}\mathbf{1 - \mathbf { R } ^ { \mathbf { 2 } }} \\
0,03\end{array}$} & \multirow{2}{*}{$\begin{array}{l}\text { MSE } \\
0,0000004\end{array}$} & \multirow{2}{*}{$\frac{\text { SE } \pm}{0,001}$} \\
\hline & Integral Plant & & & & & & & & & & & \\
\hline \multirow{3}{*}{ Glucose } & leaves & 0,019 & $-0,00022$ & 0,000020 & 0,00000079 & 0,000000082 & & & 0,91 & 0,09 & 0,00000031 & 0,001 \\
\hline & Stems & 0,020 & $-0,000357$ & 0,000038 & 0,0000022 & 0,00000034 & $-0,0000000046$ & 0,0000000009 & 0,99 & 0,01 & 0,00000004 & 0,000192 \\
\hline & Integral Plant & 0,072 & $-0,001$ & 0,000057 & 0,0000033 & 0,00000023 & & & 0,96 & 0,04 & 0,000003 & 0,002 \\
\hline \multirow[t]{3}{*}{ Sucrose } & leaves & 0,043 & $-0,001$ & 0,000046 & 0,000002 & 0,00000019 & & & 0,91 & 0,09 & 0,000004 & 0,001 \\
\hline & Stems & 0,042 & $-0,001$ & 0,000082 & 0,0000048 & 0,0000007 & $-0,0000000098$ & 0,000000002 & 0,99 & 0,01 & 0,0000002 & 0,000411 \\
\hline & Integral Plant & 0,039 & $-0,001$ & 0,000032 & 0,0000012 & 0,0000011 & & & 0,95 & 0,05 & 0,0000008 & 0,001 \\
\hline \multirow[t]{2}{*}{ Fructose } & leaves & 0,023 & $-0,000317$ & 0,000026 & 0,0000012 & 0,00000011 & & & 0,90 & 0,10 & 0,0000005 & 0,001 \\
\hline & Stems & 0,022 & $-0,000418$ & 0,000044 & 0,0000026 & 0,00000039 & $-0,0000000054$ & 0,000000001 & 0,99 & 0,01 & 0,000000049 & 0,000223 \\
\hline
\end{tabular}

$\mathrm{R}^{2}$ todos a $\mathrm{p}<0,001$ 
Table 2. Relationship between regrowth age, sugars content and sugars of Tithonia diversifolia in the dry season

\begin{tabular}{|c|c|c|c|c|c|c|c|c|c|c|c|c|}
\hline \multicolumn{2}{|c|}{ Indicadors } & $\mathbf{A}$ & B & SE \pm & $\mathrm{C}$ & $\mathrm{SE} \pm$ & d & SE \pm & $\mathbf{R}^{2}$ & $1-R^{2}$ & MSE & SE \pm \\
\hline \multirow{3}{*}{ Glucose } & Integral Plant & 0,010 & $-0,000049$ & 0,000003 & 0,00000014 & 0,000000013 & \multirow{3}{*}{0,0000000015} & \multirow{3}{*}{0,0000000004} & 0,99 & 0,01 & 0,000000007 & 0,000085 \\
\hline & leaves & 0,003 & 0,000056 & 0,000015 & $-0,00000053$ & 0,00000013 & & & 0,50 & 0,50 & 0,000000006 & 0,000075 \\
\hline & Stems & 0,005 & $-0,000044$ & 0,000003 & 0,00000011 & 0,000000012 & & & 0,99 & 0,01 & 0,000000007 & 0,000083 \\
\hline \multirow{3}{*}{ Sucrose } & Integral Plant & 0,004 & 0,000155 & 0,000015 & $-0,00000074$ & 0,000000061 & & & 0,93 & 0,07 & 0,00000017 & 0,000412 \\
\hline & leaves & $-0,001$ & 0,000164 & 0,000011 & $-0,00000068$ & 0,000000044 & & & 0,92 & 0,08 & 0,000000089 & 0,00003 \\
\hline & Stems & 0,005 & $-0,0000093$ & 0,000005 & $-0,000000067$ & 0,000000021 & & & 0,99 & 0,01 & 0,000000019 & 0,000139 \\
\hline \multirow{3}{*}{ Fructose } & Integral Plant & $-0,006$ & 0,000206 & 0,000016 & $-0,00000089$ & 0,000000067 & & & 0,91 & 0,09 & 0,0000002 & 0,000414 \\
\hline & leaves & $-0,006$ & 0,00017 & 0,000012 & $-0,0000007$ & 0,00000005 & & & 0,91 & 0,09 & 0,00000011 & 0,00038 \\
\hline & Stems & 0,0000022 & 0,000035 & 0,000004 & $-0,00000018$ & 0,000000017 & & & 0,95 & 0,05 & 0,000000013 & 0,000113 \\
\hline
\end{tabular}

$\mathrm{R}^{2}$ todos a $\mathrm{p}<0,001$ 
http://sciforum.net/conference/mol2net-07

The high variability in sugars with age is due to the different photosynthesizing capacity of the species, related to the element potassium, which is a mediator of the metabolism and transport of primary carbohydrates in plants ${ }^{[12,13]}$.

On the other hand, the soluble carbohydrate content is linked to the morphostructural development of plants. The concentrated reserves of these compounds, in smaller quantities, in the growth points (buds) favor the foliar concentrations of the saccharides after the regrowth emission. However, although these aspects are generally described, from the physiological point of view, the behavior of energy metabolites as a function of morphostructural variations depends on the species, nutritional status and edaphoclimatic conditions in which it is grown ${ }^{[12,14]}$.

The sugar concentrations in Tithonia were similar to those obtained in the foliage of other non-legume plants such as Morus alba, Trichantera gigantea, Cnidoscolum aconitifolium and Ficus carica ${ }^{[15]}$. However, the amounts were lower than those reported in some legumes of traditional use as forage ${ }^{[16]}$, in which the level of these compounds in mature foliage's has been determined. This corroborates what has been described previously, where the intervention of different factors in the contents of said sugars is explained.

In this regard, it is known that generally, non-legumes compared to legumes have a higher foliar amount of soluble carbohydrates when both groups are in the same phenological state ${ }^{[17]}$. However, it has been shown under different experimental conditions that the age of the biomass influences the concentration of carbohydrates ${ }^{[12]}$.

Some studies indicate that photosynthesis is one of the processes that slows down at low temperatures. Despite the decrease in the sucrose synthesis indices, soluble carbohydrates such as Frut accumulate under these conditions, which indicates that their use for photosynthesis and sucrose synthesis is more strict ${ }^{[18]}$.

When evaluating ${ }^{[19]}$ the effect of water stress in pasture grasses, they found that Glu and Sac remained stable and Frut decreased by more than $50 \%$ with age. It is likely 
http://sciforum.net/conference/mol2net-07

that this response also occurs in legumes, although it would be necessary to design specific investigations to validate this hypothesis.

On the other hand, according to the reports of ${ }^{[20]}$ there is a close relationship between the carbohydrate composition, age and $\mathrm{N}$ content, on the content of secondary metabolites. According to this study, in addition to these, soil and climate conditions can determine the composition of some compounds, particularly $\alpha$-galactosides. The content of Sac and Verb could be genetically determined, while those of raffinose and stachyose depend, to a lesser extent, on environmental conditions, and fundamentally on the photosynthetic activity of plants and the production of primary metabolites.

\section{Conclusions}

The established regression equations explain the close relationship between regrowth age and the contents of precursor metabolites (Glu, Frut and Suc), which explains the fluctuations found in sugars influenced by the phenological state of the plants and photosynthetic activity of this.

\section{References (mandatory)}

[1]. Ruiz TE, Torres V, Febles G, Díaz H, González J. Empleo de la modelación para estudiar el crecimiento del material vegetal 23 de Tithonia diversifolia. Revista Cubana de Ciencia Agrícola. 2012, 46(1): 23-29.

[2]. Guerra C, Cabrera A, Fernández L. Criterios para la selección de modelos estadísticos en la investigación científica. Revista Cubana Ciencias Agrícolas. 2003; 37(1): 3-10.

[3]. Torres V, Ramos N, Lizazo D, Monteagudo F, Noda A. Modelo estadístico para la medición del impacto de la innovación o transferencia tecnológica en la rama agropecuaria. Revista Cubana de Ciencia Agrícola. 2008, 42(2):133-140.

[4]. Hernández A, Ascanio MO, Morales M, Cabrera A. Correlación de la nueva versión de clasificación genética de los suelos de cuba con las clasificaciones internacionales y nacionales: Una herramienta útil para la investigación, docencia y producción agropecuaria. EDINCA, Instituto Nacional de Ciencias Agrícolas. C. de la Habana, Cuba. 2005. $61 \mathrm{pp}$.

[5]. AOAC. Official Methods of Analysis, Ass. Off. Agric. Chem. 2000. 17th Ed. Washington, D.C. USA. 2:777-778.

[6]. Keviste A, Álvarez JG, Rojo A, Ruíz A D. Funciones de crecimiento de aplicación en el ámbito forestal. Ministerio de Ciencia y Tecnología. Instituto de Investigaciones y Tecnología Agraria y Alimentaria. Madrid. España. 2002. 190 pp. 
[7]. Torres V, Ortiz J. Application of modelling and simulation to the production and feeding of farm animals. Cuban J. Agric. Sci. 2005; 39:397-405.

[8]. Ávalos A, Pérez-Urria E. Metabolitos secundarios de plantas. Reduca (Biología). Serie Fisiología Vegetal. 2009, 2: 119-145.

[9]. Ramírez JL. Rendimiento y valor nutritivo de cinco gramíneas en el Valle del Cauto. [Tesis de Doctorado]. Universidad de Granma, Cuba. 2010. 101.

[10]. Ramírez JL, Herrera RS, Leonard I, Cisneros M, Verdecia D, Álvarez Y, López B. Relationship between quality indicators and age indicators in Pennisetum purpureum vc. Cuba CT-169 in Cauto Valley, Cuba. Cuban J. Agric. Sci. 2012, 46: 315-319.

[11]. Verdecia DM, Herrera RS, Ramírez JL, Leonard I, Álvarez Y, Bazán Y, Arceo Y, Bodas R, Andrés S, Álvarez J, Giráldez FJ, López S. Valor nutritivo de Leucaena leucocephala con énfasis en el contenido de metabolitos secundarios. Revista Electrónica de Veterinaria (REDVET). 2012, 13. Disponible en: http://www.veterinaria.org/revistas/redvet/n111112/111213.pdf. [Consultado: 5 de junio de 2017].

[12]. Pineda M. 2004. Resúmenes de Fisiología vegetal. Servicios de publicaciones de la Universidad de Córdoba, Córdoba, España. 2004. 204. Disponible en: www.uco.es/publicaciones/revistas.html [Consultado 14 de octubre de 2016].

[13]. García DE, Medina MG, Ojeda F, Humbría J, Domínguez CE, Baldizán A, Toral O. Variabilidad fitoquímica y repercusión antinutricional potencial en especies del género Albizia. Pastos y Forrajes. 2006, 29:231-241.

[14]. Benavides JE. La investigación en árboles forrajeros. En: Benavides JE. (Ed.) Árboles y Arbustos Forrajeros en América Central. Informe Téc. No. 236. CATIE. Turrialba, Costa Rica. 1994, 1: 3-21.

[15]. García C, Martínez A, Ortega JL, Castro F. Componentes químicos y su relación con las actividades biológicas de algunos extractos vegetales. Revista Química Viva. 2010, 9: 86-96.

[16]. Benavides JE. La investigación en árboles forrajeros. En: Benavides JE. (Ed.) Árboles y Arbustos Forrajeros en América Central. Informe Téc. No. 236. CATIE. Turrialba, Costa Rica. 1994, 1: 3-21.

[17]. García DE. Los metabolitos secundarios de las especies vegetales. Pastos y Forrajes. 2004, 27: 1-12.

[18]. Chatterton NJ, Harrison PA, Thornley WR. Loliose: a novel trisaccharide in leaves of Loliumand festuca species. Plant Physiol. 1993, 12:113-116.

[19]. Aimard V, Morvan A, Billard J, Huault C, Keller F, Prud M. Fructans, but not the sucrosyl-galactosides, raffinose and loliose, are affected by drought stress in perennial ryegrass. Plant. Physiology. 2003, 132: 2218-2229.

[20]. Trugo LC, Farah A, Cabral L. Oligosaccharides distribution in Brazilian soya bean cultivars. Food Chem. 1988, 52: 385-387. 


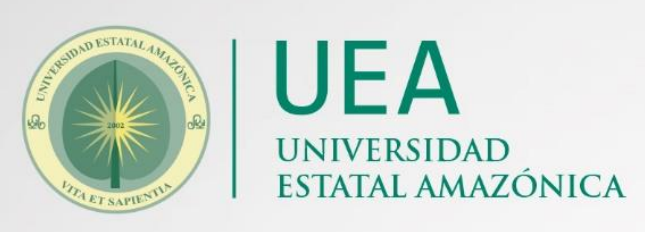

\section{MODECOOG}

Diversidad Molecular, Producción de Energía
y Ecosistemas, del Amazonas a los Océanos

invita a la a la comunidad universitaria de la UEA, instituciones de educación superior y estratégicas del Ecuador y ciudadanía en general, involucradas en áreas de:
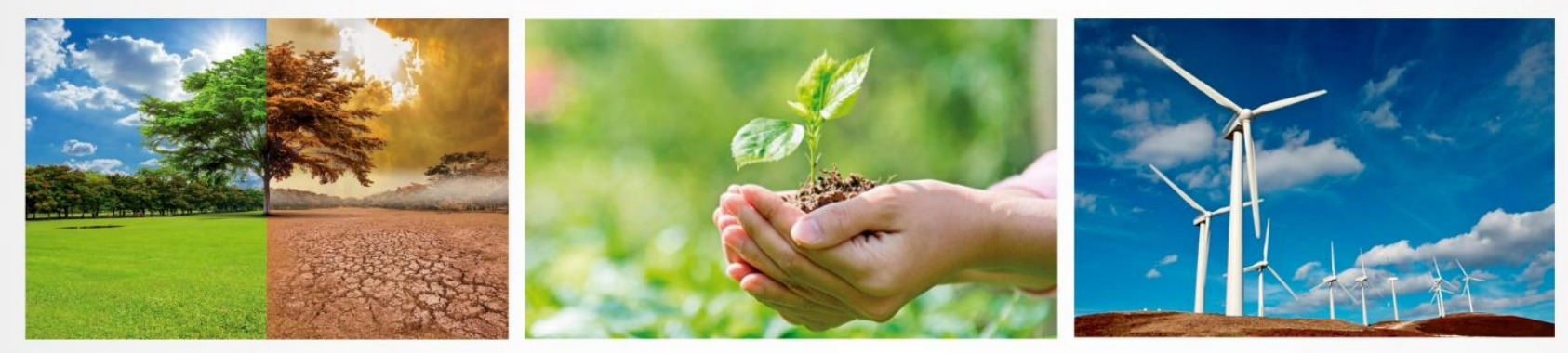

- Conservación de Ecosistemas

- Producción de Energía

- Impacto Climático

- Desarrollo de Productos Naturales y Procesos Agroindustriales, entre otras.

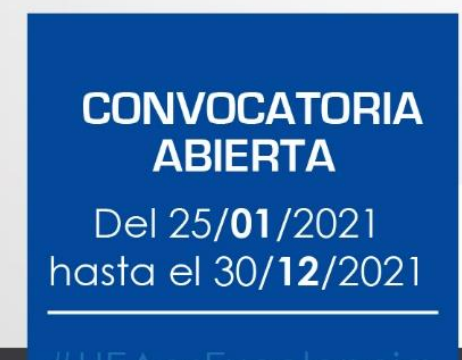
Presentar sus trabajos de investigación, para su difusión en el taller interuniversitario transatlántico, MODECO-06, sin costo alguno.

Del 25/01/2021 hasta el 30/12/2021 